\title{
PEMBUATAN ALAT PENGERING IKAN RAMAH LINGKUNGAN DENGAN MENGGUNAKAN PANEL SURYA
}

\author{
Yusak Mukkun', Sumartini Dana²
}

\begin{abstract}
Abstrak :
Alat pengering ikan asin ramah lingkungan menggunakan integrasi panel surya dan energi matahari merupakan hasil pengembangan energi terbarukan yaitu pemanfaatkan energi matahari baik secara langsung maupun secara tidak langsung dengan penyimpanan solar cell, yang penggunaannya dimaksimalkan dan diunggulkan untuk meningkatkan kesejahteraan nelayan pesisir pantai dengan produk yang didesain sedemikian rupa agar dihasilkan ikan kering yang bermutu dan higienis untuk dikonsumsi, mengurangi ketergantungan pada cuaca, menekan kerugian yang dialami para nelayan pada saat panen raya, memperkecil kemungkinan kerusakan yang diakibatkan pembusukan, dan mempercepat proses dan tidak memerlukan lahan yang luas. Sinar matahari langsung dan alat tambahan seperti fan atau blower diperlukan untuk mengalirkan udara pengering ke produk yang dikeringkan (konveksi paksa) dan sensor suhu sebagai pengontrol suhu dan diharapkan temperatur pengeringan yang lebih tinggi dari $50^{\circ} \mathrm{C}$ harus dihindari karena dapat menyebabkan bagian luar produk sudah kering, tapi bagian dalam masih basah. Khusus untuk ikan, temperatur pengeringan yang dianjurkan antara $40-50^{\circ} \mathrm{C}$. Ikan kering berbagai jenis yang dihasilkan dalam kapasitas $10 \mathrm{~kg}$ pada alat pengering ikan tanpa lampu pijar 15 Watt dengan waktu pengeringan selama 3 hari, menggunakan lampu pijar 15 watt pada malam hari, waktu pengeringan ikan mencapai 2 hari dan menggunakan lampu pijar 15 watt ditambah kipas angin pada malam hari, waktu pengeringan ikan mencapai 2 hari.
\end{abstract}

Kata kunci : Panel solar cell, Sinar matahari langsung proses pengering ikan.

\section{PENDAHULUAN}

Pemanfaatan wilayah pesisir dan lautan Desa Oesapa Kupang sangat potensil dan beragam, baik dari usaha perikanan (tangkap, budidaya dan pengolahan). Dengan potensi yang sedemikian melimpah, nelayan di pesisir pantai Oesapa Kupang, akan dapat dengan mudah menangkap banyak ikan.

Ikan yang diperoleh tidak semua dijual kepasar tetapi dikeringkan untuk dibuat ikan asin. Kendala atau kesulitan mereka selain pemasaran untuk pengusaha pengasinan ikan bersekala kecil, terletak pada pengering ikan. Mereka pada umumnya masih menggunakan cara tradisional dalam mengeringkan ikan hasil tangkapan dan masih menggantungkan diri pada alam, yaitu sinar matahari. Untuk musim kemarau, dimana matahari berlimpah dan tidak ada awan yang menutup matahari, usaha pengeringan mereka berjalan dengan baik. Nelayan dapat menghasilkan ikan kering dengan berbagai jenis dan ukuran, hasil yang diperoleh 1 ton sedangkan jika pada musim penghujan, dimana matahari bersinar tidak terlalu baik dan sering terjadi mendung, pendapatan mereka menurun drastis. Ikan yang dijemur akan kering sesuai dengan tingkat kekeringan tertentu yang diinginkan pasar setelah berhari-hari di jemur 


\section{Jurnal Ilmiah FLASH Volume 2 Nomor 2 Desember 2016}

dan mereka hanya menghasilkan ikan asin hanya setengah ton, sehingga harga jual ikan asin pada saat musim hujan sangat tinggi.

Dari hasil peninjauan tim peneliti kelokasi pesisir pantai Oesapa Kupang Nusa Tenggara Timur menunjukan bahwa proses pembuatan ikan asin masih secara sederhana atau tradisional yaitu ikan laut dipilah-pilah berdasarkan jenis dan ukuran dikumpulkan dalam suatu wadah lalu ditaburi atau direndam dalam larutan garam pekat. Ikan-ikan yang besar biasanya dibelah atau dipotong-potong lebih dulu agar garam mudah meresap ke dalam daging, kemudian baru dijemur di bawah terik matahari panas. Pembuatan ikan asin dengan kombinasi penggaraman kering dan basah, lkan dicampur dengan kristal garam dengan perbandingan 3 : 1 atau $4: 1$ di dalam bak semen. Campuran ini disiram dengan larutan garam jenuh sebanyak 500 liter untuk 2 - 2.5 ton ikan. dan dibiarkan satu sampai tiga malam, tergantung pada cuaca. Setelah penggaraman cukup dan cuaca memungkinkan, ikan diangkat dan dibilas dengan air, kemudian dijemur.

Penambahan garam yang biasa dilakukan oleh para nelayan berkisar antara 20 sampai 40 persen berat ikan, kadang-kadang sampai 60 100 persen berat ikan. Lama pengeringan berkisar antara 1 - 6 hari. Pada cuaca yang baik, pengeringan ikan-ikan kecil seperti teri cukup dilakukan selama 5 - 7 jam, sedangkan ikan berukuran sedang membutuhkan waktu 2 hari, dan ikan berukuran besar mernbutuhkan lebih lama kadang-kadang sampai 4 hari.

Beberapa produk ikan asin yang berukuran kecil misalnya teri asin putih, teri asin hitam, teri tambang (lemet), teri nasi dan jambrong. Ikan-ikan berukuran sedang yang sering diawetkan dengan pengasingan misalnya petek, selar. layang dan sarden, sedangkan ikan asin yang terbuat dari ikan berukuran besar yang telah rnengalami pembelahan dan penyiangan pada waktu pernbuatannya meliputi ikan tenggiri, tongkol, pari, jarnbal dan cucut.

Jika dilihat dari segi higienis, cara ini dirasakan kurang baik, karena selain terkena udara bebas yang memiliki banyak kandungan virus dan kuman, ikan juga dihinggapi oleh lalat yang banyak membawa kuman penyakit. Pengolahannya biasanya menggunakan rak-rak anyaman bamboo, seng, terpal dan apabila panen raya, ikan-ikan yang akan dikeringkan dijemur di permukaan pantai tanpa alas.

Permasalahannya bagaimana proses pembuatan ikan asin yang dikelola oleh masyarakat maupun pengusaha perlu adanya sentuhan teknologi yang mendukung masyarakat dalam pengolahan ikan asin. Teknologi pengolahan Ikan asin ramah lingkungan dengan menggunakan solar cell menjadi solusi bagi masyarakat pesisir pantai Desa Oesapa. Energi matahari menghasilkan panas dengan temperature yang dapat disesuaikan untuk proses pembuatan ikan asin. Menurut Bahari (2010), temperatur mencapai $106{ }^{\circ} \mathrm{C}$ dan dapat disimpan panas tersebut selama 12 jam dengan temperature terendah $50{ }^{\circ} \mathrm{C}$.

Untuk memperoleh kualitas pengeringan yang bagus, ada beberapa parameter yang harus dikontrol selama proses pengeringan, yaitu kecepatan aliran udara, temperatur udara pengering dan kelembaban relatif udara. Kecepatan aliran udara yang tinggi dapat mempersingkat waktu pengeringan. Kecepatan aliran udara yang disarankan untuk melakukan proses pengeringan antara $1,5-2,0 \mathrm{~m} / \mathrm{s}$. Kamaruddin, A. (2003).

Nilai keunggulan lain dari alat ini adalah tidak memerlukan lahan yang luas dan dapat dipindah-pindahkan. Pengoperasiannya juga tidak sulit, alat ini didesain khusus selain dapat diletakan di tempat terbuka jika cuaca baik, sinar matahari bisa focus menyinari kaca-kaca pengumpul panas yang bertujuan untuk proses pengeringan ikan. Namun jika cuaca mendung atau hujan alat ini bisa mengguakan panel solar sel sebagai catu daya untuk proses pengeringan ikan asin. Alat ini sangat sesuai dalam pengembangan teknologi dan berguna untuk pengembangan ilmu pengetahuan dan teknologi dalam membantu pemerintah menuntaskan kemiskinan didaerah-daerah terpencil. 

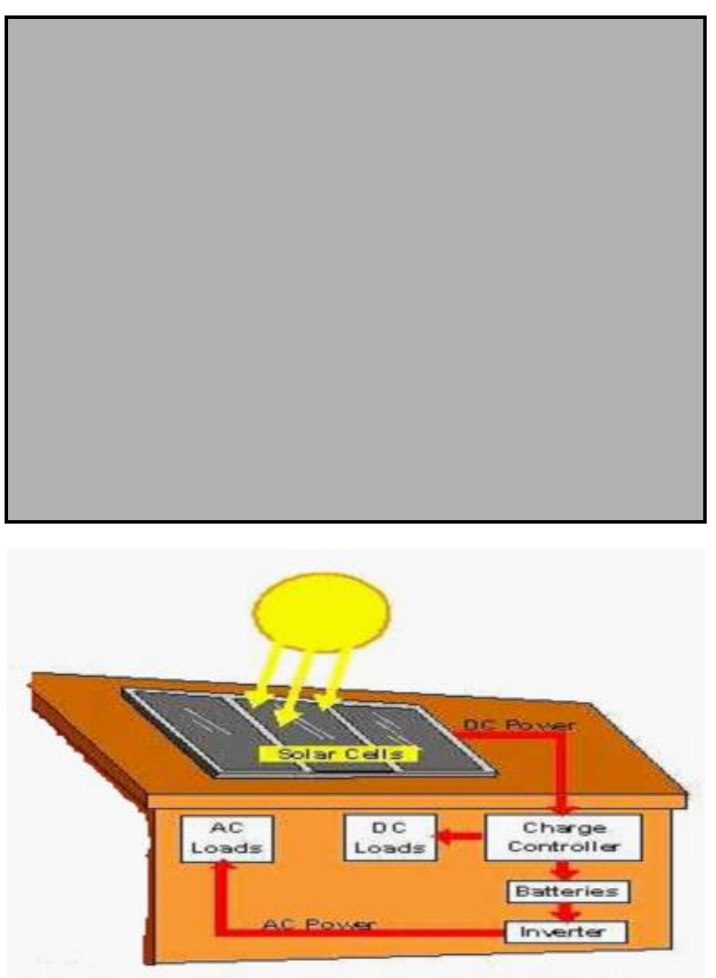

Gambar 2. Pemasangan Pembangkit Listrik Tenaga Surya untuk Pengering Ikan

\section{Penjelasan Blok Diagram :}

Prinsip kerja dari pengering ikan ini yaitu dengan mengonversikan energi matahari pada modul sel surya (PV) menjadi energi listrik. Energi tersebut kemudian ditampung pada baterai atau aki dengan menggunakan charge controler. Arus listrik DC yang ditampung dalam Aki akan dikonversikan menggunakan inverter menjadi tegangan arus listrik AC yang disalurkan ke kipas dan pemanas yang berada dalam Rak pengering ikan.

Kipas pada rak berfungsi untuk mengalirkan udara atau membuang gas pada rak pengering ikan tersebut, dan pemanas digunakan untuk mengeringkan kandungan air pada ikan yang diletakkan atau yang ditampung pada rak pengering ikan. Sedangkan sensor suhu yang diletakkan pada rak berfungsi untuk mengontrol suhu dalam rak pengering agar ikan dalam rak sesuai dengan suhu yang diinginkan dalam pengeringan.

\section{Peralatan}

\section{Panel Surya}

Panel surya adalah alat yang digunakan untuk mengubah sinar matahari menjadi listrik. Dalam sinar matahari terkandung energi dalam bentuk foton. Ketika foton ini mengenai permukaan sel surya, elektronelektronnya akan tereksitasi dan menimbulkan aliran listrik. Prinsip ini dikenal sebagai prinsip fotoelektrik. Sel surya dapat tereksitasi karena terbuat dari material semikonduktor yang mengandung unsur silikon. Silikon ini terdiri atas dua jenis lapisan sensitif: lapisan negatif (tipe-n) dan lapisan positif (tipe-p).

\section{Solar Charge Controller}

Spesifikasi Komponen Kelistrikan Alat Pengering Ikan

Komponen-komponen yang dibutuhkan pada proses pengeringan ikan.

\section{Modul photovoltaic}

Berfungsi sebagai menkonversi energi matahari menjadi energi listrik digunakan untuk suplai energi listrik pada peralatan pengering ikan. Modul yang dipakai $100 \mathrm{wp}$, maka daya yang dihasilkan 100 watt/hour. Spesifikasi produk

Max. Power (Pmax) : $100 \mathrm{WP}$

Max. Power voltage (Vmp): $19.6 \mathrm{~V}$

Max. Power current (Imp) : $5.1 \mathrm{~A}$

Open Circuit Voltage (Voc): $24 \mathrm{~V}$

Short Circuit Current (Isc) : 5,51 A

Nominal Operating Cell Temp (NOCT) : $45 \pm 2^{\circ} \mathrm{C}$

$\begin{array}{ll}\text { Max. System Voltage } & : 1000 \mathrm{~V} \\ \text { Max. Series Fuse } & : 16 \mathrm{~A} \\ \text { Dimension } & : 1085 \times 675 \times \\ & 25 \mathrm{~mm}\end{array}$

\section{Solar charge Regulator}

Berfungsi sebagai pengatur tegangan dari suplai modul photovoltaic ke pengisian baterai dan suplay inverter.

Spesifikasi produk

Ratings

: 12/24 Volt auto Work

Regulation point 


\section{Jurnal Ilmiah $F$ LASH Volume 2 Nomor 2 Desember 2016}

$\begin{array}{ll}\text { Low Voltage Disconnect } & : 11.1 \text { Volt } \\ \text { Low voltage Reconnect } & : 13.1 \text { Volt } \\ \text { Type of charging } & : \text { series PWM } \\ \text { Self Consumption } & : 6 \mathrm{~mA} \\ \text { Terminals } & : \text { for wire Sizes to } \\ & 2.5 \mathrm{~mm} \\ \text { Temperature } & :-35^{\circ} \mathrm{C} \text { to }+55^{\circ} \mathrm{C} \\ \text { Weight } & : 250 \mathrm{~g} \\ \text { Dimension } & : 140 \times 90.5 \mathrm{~mm}\end{array}$

\section{Baterry (AKI)}

Berfungsi untuk menyimpan energi dari modul photovoltaic dipakai sebagai suply cadangan untuk malam hari sehingga alat tetap beroperasi.

Spesifikasi produk

$\begin{array}{ll}\text { Rated voltage } & : 12 \mathrm{~V} \\ \text { Rated capacity } & : 100 \mathrm{Ah} \\ \text { Lenght } & : 330 \mathrm{~mm} \\ \text { Width } & : 171 \mathrm{~mm} \\ \text { Height } & : 214 \mathrm{~mm}\end{array}$

\section{Inverter}

Berfungsi sebagai pengubah tegangan masuk dari solar regulator yang berupa tegangan DC yang kemudian dikonversikan menjadi tegangan $\mathrm{AC}$ agar dapat menyuplai tegangan ke termometer kontrol, kipas dan Lampu.

Spesifikasi Produk

Input voltage $\quad: 12 \mathrm{~V}$

Output voltage $\quad: 220 \mathrm{~V} \mathrm{AC}$

Output frequency $\quad: 50 \mathrm{~Hz}$

Input voltage range $\quad: 10-15 \mathrm{~V}$

Low battery alarm $\quad: 10.4-11 \mathrm{~V}$

Low battery shutdown point $: 9.7-10.3 \mathrm{~V}$

High battery shutdown point : $14.5-15.5 \mathrm{~V}$

\section{Temperatur kontrol}

Berfungsi sebagai pengatur suhu dalam rak pengering ikan. Range temperatur yang dikontrol ditentukan sesuai dengan set point yang diinginkan yaitu sekitar $35-45^{\circ} \mathrm{C}$. jika temperatur kurang dari $35^{\circ} \mathrm{C}$ maka lampu sebagai sumber panas akan menyala, sebaliknya jika temperatur lebih dari $45^{\circ} \mathrm{C}$ maka lampu akan padam. Temperature controller yang digunakan adalah Dual Auto Tuning PID Controller Type TZN4H.

Spesifikasi produk

Type : Dual PID Auto Tuning

Model : TZN4H

Allowable Voltage range : $90-110 \%$

Power consumption : 5 VA

Display method : 7 segment LED display

Power supply $: 100-220$ VAC

Alarm output : 250 VAC 3 A 1C Relay

Control output : current

Sampling Time $: 0.5 \mathrm{sec}$

Option output : 1 Alarm

Dimension : $48 \times 96 \mathrm{~mm}$

\section{Sensor suhu RTD}

Merupakan Sensor temperatur yang mengukur temperatur riil dalam ruangan, kemudian di ubah kedalam besaran listrik sehingga dapat dihubungkan dengan temperature kontrol.

Spesifikasi

Type : RTD PT100

Output resistansi : $-243^{\circ} \mathrm{C}-600^{\circ} \mathrm{C}$

Panjang stick $: 4 \mathrm{~cm}$

Diameter drat $: 0.8 \mathrm{~cm}$

Panjang kabel $: 83 \mathrm{~cm}$

\section{Lampu pijar}

Lampu pijar dalam pengoperasiannya dapat menghasilkan panas sehingga dapat digunakan sebagai sumber panas pada pengering ikan untuk malam hari.

Spesifikasi produk

Type : lampu pijar philips 40 watt

Supply : $220-240 \mathrm{~V}$

Berat : 70 gram

Permasalahan yang akan diteliti dalam melaksanakan penelitian membuat teknologi Pembuatan alat pengering ikan ramah lingkungan dengan menggunakan integrasi panel surya dan sinar matahari langsung terdiri atas:

a)Bagaimana merancang dan menganalisis sistem kontrol suhu panas yang merata dan stabil di dalam ruang rak pengering ikan. 
b)Bagaimana merancang dan menganalisis sistem pembuangan limbah ikan melalui pipa didalam rak pengering supaya dapat berfungsi dengan baik.

c)Bagaimana cara memasang kipas pada rak pengering ikan agar dapat berfungsi sebagai pendingin suhu secara merata dan baik.

d)Bagaimana cara memasang dan mengintegrasikan panel surya dan matahari langsung dalam rak pengering ikan sehingga dapat digunaka secara bergantian dengan tepat dan benar.

e)Temperatur pada alat pengering ikan disesuaikan dengan temperatur panas matahari pada saat cuaca baik yang digunakan nelayan untuk mengeringkan ikan dengan hasil daging ikan kering merata dan sempurna (dengan asumsi temperatur pengeringan yang lebih tinggi dari 50C harus dihindari karena dapat menyebabkan bagian luar produk sudah kering, tapi bagian dalam masih basah).

Tujuan khusus dalam penelitian adalah: Untuk menghasilkan alat pengolahan ikan asin ramah lingkungan dengan menggunakan integrasi panel surya dan energi matahari langsung di pesisir pantai Desa Oesapa Kupang Nusa Tenggara Timur, sehingga dapat meningkatkan produksi ikan asin bagi kelompok nelayan di Desa Oesapa Kabupaten Kupang Propinsi Nusa Tenggara Timur

\section{METODOLOGI}

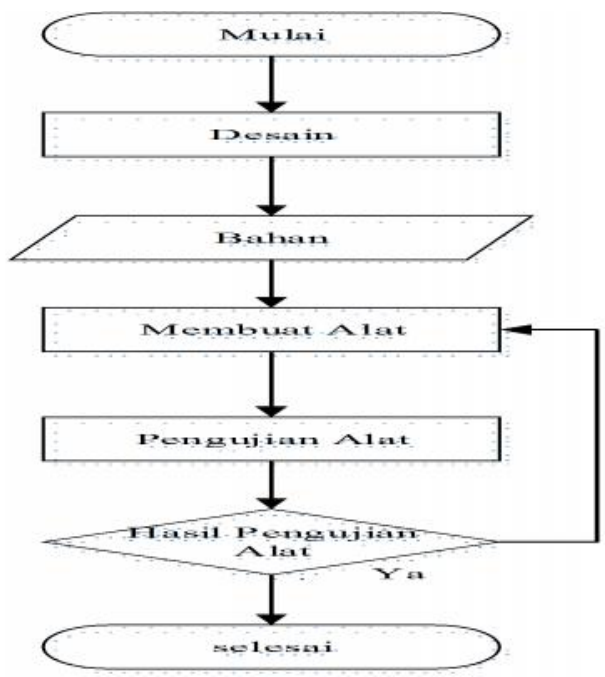

Gambar 3. Diagram Flowchart PembuatanAlat pengering ikan

\section{HASIL DAN PEMBAHASAN}

\subsection{Hasil}

Dalam proses pembuatan alat pengering ikan tahapan yang paling pertama dilakukan adalah mendesain alat. Alat di desain sedemikian rupa agar bisa menampung ikan untuk proses pengeringan. Alat pengering ikan ini dirancang agar bisa ditempatkan diluar ruangan dengan bantuan energi matahari sebagai pengeringan dan sumber catu daya untuk digunakan sebagai sumber energi pada komponen kelistrikan seperti temperatur kontrol, lampu dll. Alat pengering ikan didesain memiliki rak agar memperbanyak jumlah ikan pada proses pengeringan.

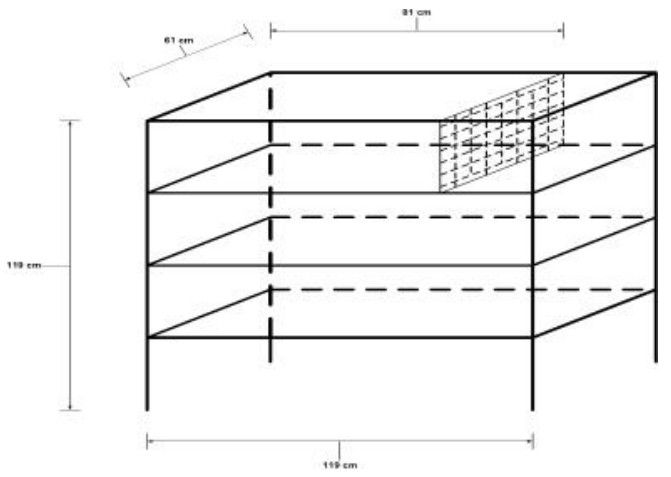

Gambar 4. Desain alat pengering ikan 


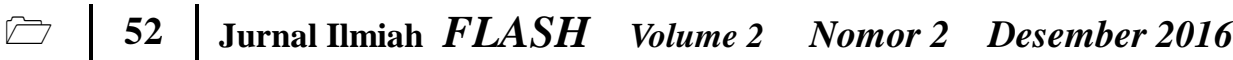

\begin{tabular}{|l|l|}
\hline No & $\begin{array}{l}\text { Kegiatan yang sudah } \\
\text { dilaksanakan }\end{array}$ \\
\hline 1 & $\begin{array}{l}\text { Membuat rak penge- } \\
\text { ring ikan ramah ling- } \\
\text { kungan dengan meng- } \\
\text { gunakan integrasi } \\
\text { panel surya dan sinar } \\
\text { matahari langsung } \\
\text { berdasarkan hasil ran- } \\
\text { cangan penelitian. } \\
\text { Pada gambar terlihat } \\
\text { dibuat tiga rak untuk } \\
\text { menempatkan ikan } \\
\text { dengan berbagai jenis } \\
\text { dan ukuran, rak dibuat } \\
\text { dari plat almunium } \\
\text { ukuran 3 mili }\end{array}$ \\
\hline 2 & $\begin{array}{l}\text { Model alat pengering } \\
\text { ikan ramah lingkungan } \\
\text { dengan menggunakan } \\
\text { integrasi panel surya } \\
\text { dan sinar matahari } \\
\text { langsung berdasarkan } \\
\text { hasil rancangan } \\
\text { penelitian }\end{array}$ \\
\hline 5 & $\begin{array}{l}\text { Pemasangan pipa } \\
\text { sebagai tempat menga- } \\
\text { lirnya limbah alat } \\
\text { pengering ikan ramah } \\
\text { lingkungan dengan } \\
\text { menggunakan inte- } \\
\text { grasi panel surya dan } \\
\text { sinar matahari lang- } \\
\text { sung berdasarkan hasil } \\
\text { rancangan penelitian }\end{array}$ \\
\hline 4 & $\begin{array}{l}\text { Memasang engsel dan } \\
\text { baut alat pengering } \\
\text { ikan ramah lingkungan } \\
\text { dengan menggunakan } \\
\text { integrasi panel surya } \\
\text { dan sinar matahari } \\
\text { penelitian rancangan } \\
\text { langsung berdasarkan } \\
\text { hasil rancangan } \\
\text { penelitian } \\
\text { ikan ramah lingkungan } \\
\text { dengan menggunakan } \\
\text { integrasi panel surya }\end{array}$ \\
\hline
\end{tabular}

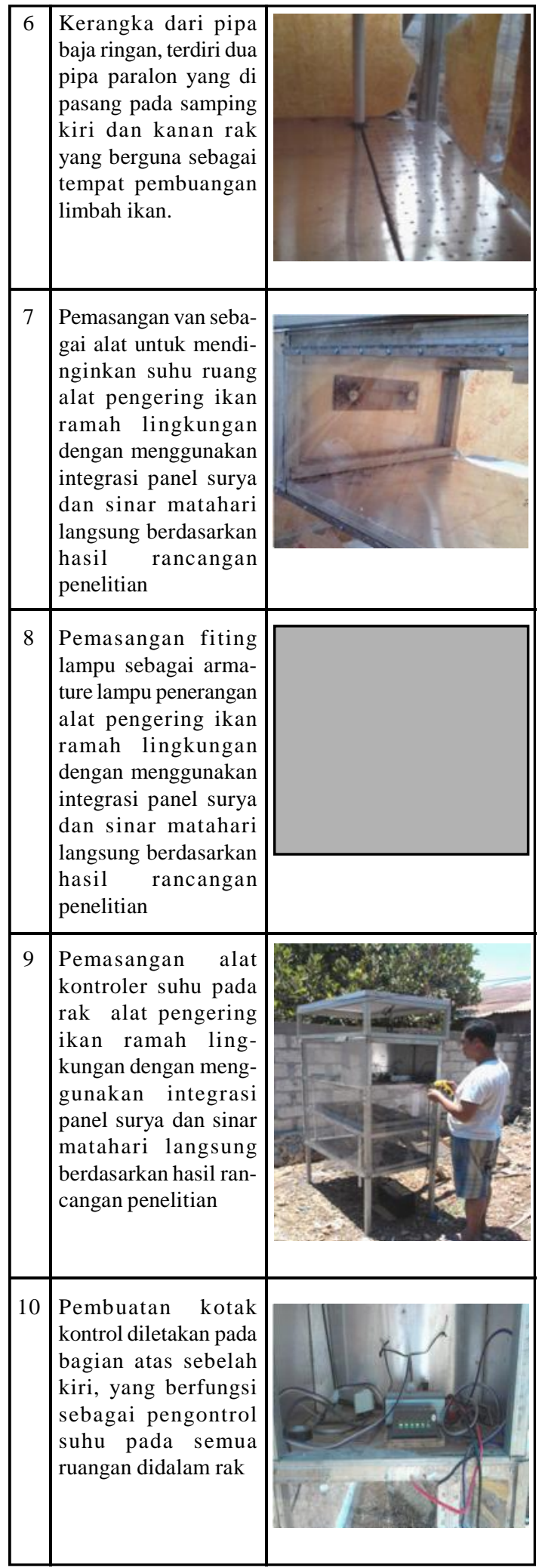




$11 \begin{aligned} & \text { Termometer suhu } \\ & \text { ruangan ditempatkan } \\ & \text { didalam alat pengering } \\ & \text { ikan untuk mengukur } \\ & \text { suhu ruangan }\end{aligned}$

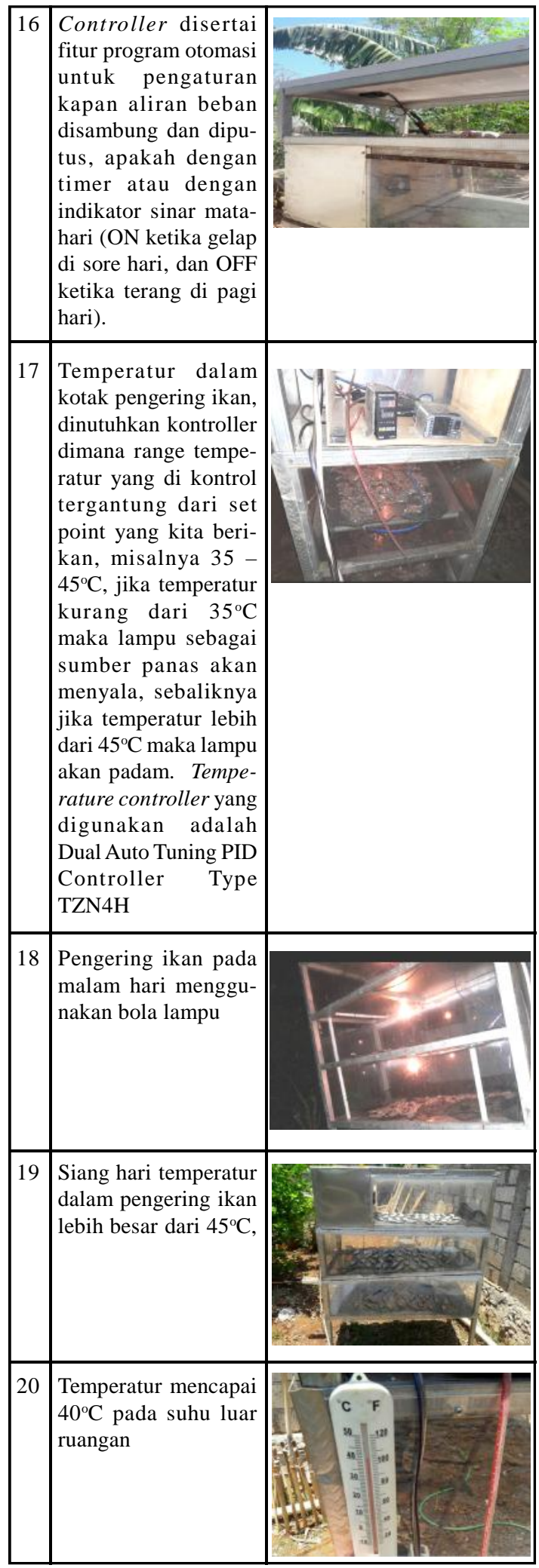




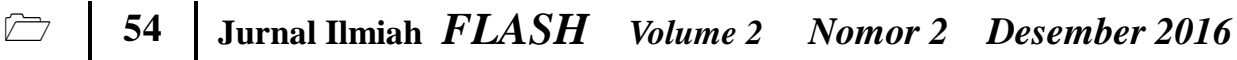

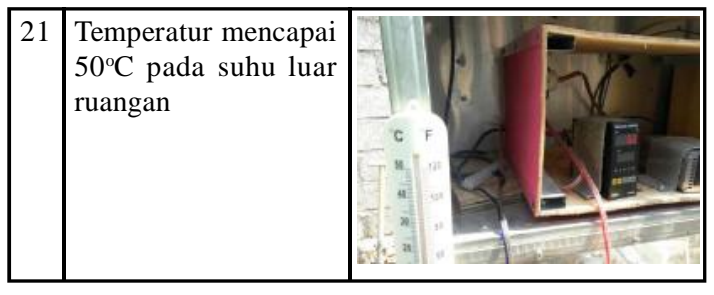

\subsection{Pembahasan}

\section{Data pengujian kestabilan suhu panas tanpa beban}

Data pengujian kestabilan suhu panas didalam ruang alat pengering ikan ramah lingkungan dengan menggunakan integrasi panel surya dan sinar matahari langsung. Pada tahapan ini baru dilakukan pengujian menggunakan sinar matahari langsung, belum diintegrasikan dengan panel surya.

Hasil pengamatan proses pengeringan dengan $45^{\circ} \mathrm{C}$ adalah sebagai berikut ditunjukkan oleh Tabel 5.2 dibawah.

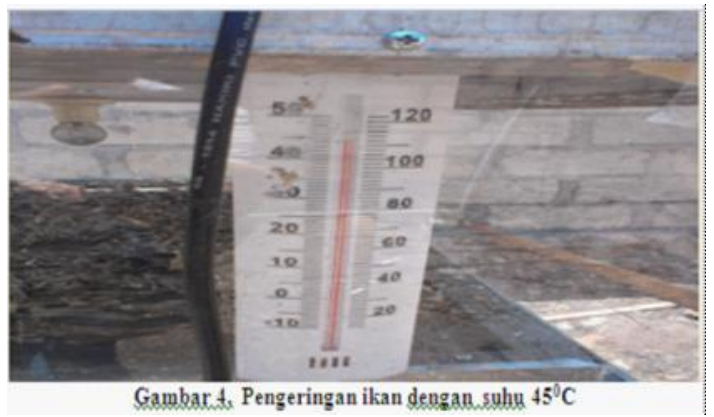

Hasil pengujian dengan matahari langsung menunjukkan Suhu kamar/ruangan tempat ikan sebesar $45^{\circ} \mathrm{C}$, sedangkan di luar ruangan mencapai 380C. Dari hasil pengamatan dimana terjadi perbedaan suhu antar suhu luar dan dalam ruangan, dengan adanya perbedaan ini menyebabkan waktu pengeringan ikan lebih cepat bila dibandingkan pengeringan dengan sinar matahari langsung. Jika dengan matahari langsung diperlukan waktu selama 1 - 2 hari jika cuaca cerah. Dengan menggunakan peralatan atau ruang, intensitas sinar matahari akan mengalami peningkatan karena tidak adanya tiupan angin, panas yang ditimbulkan akan menyebabkan terlepasnya molekul air yang terikat pada daging ikan. Air ini akan mengalir dengan sendirinya melalui saluran yang ada dalam ruangan untuk dibuang keluar. Dengan menggunakan ruangan aktivitas bakteri juga tidak ada sehingga tidak menimbulkan bau busuk pada ikan, suhu yang diterima oleh ikan konstan menyebabkan laju pengeluaran air kontinyu.

Tabel 2, Hasil Pengamatan Proses Pengeringan dengan suhu $45^{\circ} \mathrm{C}$
\begin{tabular}{c|c|c|c|}
\hline Waktu (mnt) & KA & Suhu & RH \\
\hline 0 & 20,10 & 34,4 & 72,9 \\
\hline 20 & 18,67 & 35,5 & 77,8 \\
\hline 30 & 17,80 & 36,3 & 76,5 \\
\hline 40 & 15,77 & 37,5 & 71,4 \\
\hline 60 & 13,60 & 37,6 & 66,6 \\
\hline 70 & 11,48 & 38,1 & 63,2 \\
\hline 80 & 9,56 & 38,3 & 65,1 \\
\hline 90 & 8,05 & 38,4 & 69,7 \\
\hline
\end{tabular}

Dari tabel 2 terlihat bahwa waktu yang diperlukan untuk menurunkan kadar air bahan sampai $8,05 \%$ dengan waktu selama 90 menit. Waktu ini lebih cepat bila dibandingkan pengeringan dengan sinar matahari selama 1 2 hari pengeringan. Hal ini disebabkan suhu yang diterima bahan konstan menyebabkan laju pengeluaran air dari daging ikan berlangsung kontinyu.

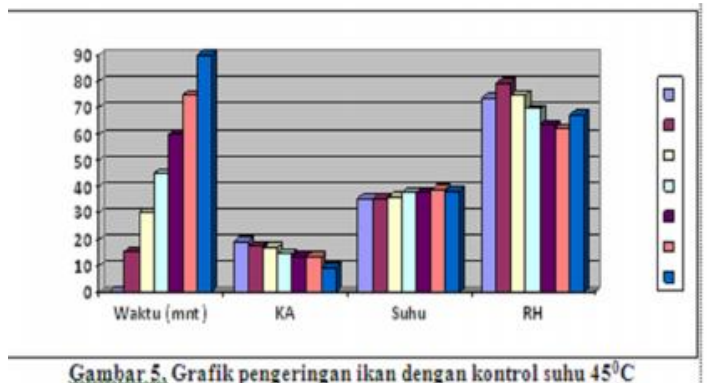

Dari Gambar 2 terlihat bahwa nilai RH makin menurun namun kadar air mengalami penurunan berkisar pada suhu rata-rata 37.07 derajat celcius. Hal ini disebabkan oleh ruangan yang tertutup sehingga adanya kosentrasi panas dan saat awal kandungan air pada ikan menyerap panas sehingga mengalami pelepasan molekul air pada daging ikan. 
Tabel 3. hasil pengujian dimalam hari

\begin{tabular}{|c|c|c|c|c|}
\hline PENGUJIAN & TANGGAL & JAM & $\begin{array}{c}\text { SUHU } \\
\left({ }^{\circ} \mathrm{C}\right)\end{array}$ & KETERANGAN \\
\hline \multirow[t]{11}{*}{$\begin{array}{l}\text { Pengujian } \\
\text { tanpa Lampu } \\
\text { Pijar }\end{array}$} & $\begin{array}{l}10 / 11 / \\
2015\end{array}$ & 8,00 & 45 & $\begin{array}{c}\text { Lama } \\
\text { pengeringan } 3 \\
\text { hari }\end{array}$ \\
\hline & & 10,15 & 49 & \\
\hline & & 11,00 & 50 & \\
\hline & & 12,00 & 46 & \\
\hline & & 14,00 & 50 & \\
\hline & & 15,00 & 48 & \\
\hline & & 17,00 & 46 & \\
\hline & & 18,00 & 40 & \\
\hline & & 19,00 & 32 & \\
\hline & & 20,00 & 32 & \\
\hline & & 21,00 & 31 & \\
\hline $\begin{array}{l}\text { Pengujian } \\
\text { d e n g a n } \\
\text { Lampu Pijar } \\
15 \text { watt }\end{array}$ & $\begin{array}{l}14 / 11 / \\
2015\end{array}$ & & & $\begin{array}{c}\text { Lama } \\
\text { pengeringan } 2 \\
\text { hari }\end{array}$ \\
\hline \multirow[t]{11}{*}{$\begin{array}{l}\text { pada malam } \\
\text { hari }\end{array}$} & & 8,00 & 45 & \\
\hline & & 10,15 & 48 & \\
\hline & & 11,00 & 50 & \\
\hline & & 12,00 & 46 & \\
\hline & & 14,00 & 50 & \\
\hline & & 15,00 & 49 & \\
\hline & & 17,00 & 46 & \\
\hline & & 18,00 & 40 & \\
\hline & & 19,00 & 40 & \\
\hline & & 20,00 & 37 & \\
\hline & & 21,00 & 37 & \\
\hline $\begin{array}{l}\text { D e } n g \text { a } n \\
\text { Lampu Pijar } \\
15 \text { watt }\end{array}$ & & 8,00 & 45 & $\begin{array}{c}\text { Lama } \\
\text { pengeringan } 2 \\
\text { hari }\end{array}$ \\
\hline \multirow[t]{10}{*}{$\begin{array}{l}\text { pada malam } \\
\text { hari + Kipas } \\
\text { Angin }\end{array}$} & & 10,15 & 48 & \\
\hline & & 11,00 & 50 & \\
\hline & & 12,00 & 47 & \\
\hline & & 14,00 & 50 & \\
\hline & & 15,00 & 50 & \\
\hline & & 17,00 & 46 & \\
\hline & & 18,00 & 40 & \\
\hline & & 19,00 & 40 & \\
\hline & & 20,00 & 37 & \\
\hline & & 21,00 & 37 & \\
\hline
\end{tabular}

Hasil percobaan alat pengeringan ikan ramah lingungan pada gambar 7 , ikan dengan berbagai ukuran dan jenis dikeringkan secara bersamaan pada alat pengering ikan mengalami pengeringan secara merata.

Gambar 7. Hasil pengeringan ikan dengan ukuran dan jenis yang berbeda

\section{Perancangan dan pemasangan komponen} alat pengering ikan dengan menggunakan catu daya solar cell.

Percobaan dilakukan dengan kapasitas dan ukuran ikan yang berbeda yaitu ukuran ikan sedang (ikan kombong) seberat $5 \mathrm{~kg}$ dengan jumlah ikan 40 ekor. Ikan berukuran cukup besar (ikan kakap merah) seberat $9 \mathrm{Kg}$ dengan jumlah ikan 23 ekor.

1.Uji coba ikan ukuran sedang (ikan kembung) Hasil uji coba ukuran ikan sedang dengan berat $5 \mathrm{Kg}$ dan mengukur suhu luar dan suhu dalam pengering ikan ditampilkan pada tabel 4. berikut.

Tabel 4. Hasil Pengujian Siang Hari

\begin{tabular}{|c|c|c|c|c|c|c|c|}
\hline \multirow[b]{2}{*}{ No } & \multirow[b]{2}{*}{ Tanggal } & \multirow[b]{2}{*}{ waktu } & \multicolumn{2}{|c|}{ Suhu } & \multicolumn{2}{|c|}{ Lembab } & \multirow[b]{2}{*}{ keterangan } \\
\hline & & & $\begin{array}{c}\text { Suhu } \\
\text { dalam }\end{array}$ & $\begin{array}{l}\text { Suhu } \\
\text { luar }\end{array}$ & $\begin{array}{l}\mathrm{Da} \\
\mathrm{lam}\end{array}$ & luar & \\
\hline 1 & \multirow{11}{*}{$\begin{array}{l}\overline{0} \\
0 \\
0 \\
\frac{y}{0} \\
0 \\
\text { ป }\end{array}$} & 09.00 & 35 & 30 & 33 & 38 & Cerah \\
\hline 2 & & 10.15 & 45 & 32 & 36 & 38 & Cerah \\
\hline 3 & & 12.15 & 55 & 35 & 38 & 43 & Cerah \\
\hline 4 & & 13.45 & 52 & 34 & 38 & 43 & Cerah \\
\hline 5 & & 14.10 & 48 & 34 & 36 & 40 & Berawan \\
\hline 6 & & 14.55 & 47 & 32 & 37 & 38 & Berawan \\
\hline 7 & & 15.20 & 45 & 32 & 36 & 36 & Cerah \\
\hline 8 & & 15.55 & 44 & 31 & 35 & 41 & $\begin{array}{c}\text { Tidak } \\
\text { terkena } \\
\text { sinar } \\
\text { matahari }\end{array}$ \\
\hline 9 & & 16.30 & 43 & 31 & 36 & 41 & Cerah \\
\hline 10 & & 17.10 & 43 & 30 & 35 & 48 & Cerah \\
\hline 11 & & 17.30 & 42 & 30 & 35 & 45 & Berawan \\
\hline & $\begin{array}{l}\text { Hasil } \\
\text { geringan }\end{array}$ & & wal & & & akhi & $2,60 \mathrm{Kg}$ \\
\hline
\end{tabular}




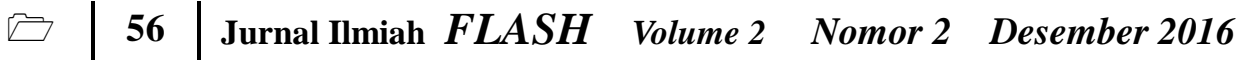

Hasil uji coba dengan ikan ukuran besar (Ikan kakap merah)

Hasil uji coba ikan ukuran ikan besar dengan berat $9 \mathrm{Kg}$ dan mengukur suhu luar dan suhu dalam pengering ikan ditampilkan pada tabel 5 . berikut.

Tabel 5. Hasil pengujian di malam hari dengan berbagai kondisi

\begin{tabular}{|c|c|c|c|c|c|c|c|}
\hline \multirow{2}{*}{ No } & \multirow{2}{*}{ Tanggal } & \multirow{2}{*}{ waktu } & \multicolumn{2}{|c|}{ Suhu } & \multicolumn{2}{|c|}{ Lembab } & \multirow{2}{*}{ Keterangan } \\
\hline & & & \begin{tabular}{|c|} 
Suhu \\
dalam
\end{tabular} & $\begin{array}{l}\text { Suhu } \\
\text { luar }\end{array}$ & dalam & luar & \\
\hline 1 & \multirow{6}{*}{ 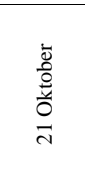 } & 18.00 & 31 & 29 & 32 & 38 & Malam hari \\
\hline 2 & & 18.40 & 31 & 29 & 34 & 31 & Malam hari \\
\hline 3 & & 19.05 & 31 & 28 & 33 & 32 & Malam hari \\
\hline 4 & & 19.45 & 30 & 29 & 32 & 34 & Malam hari \\
\hline 5 & & 20.10 & 31 & 27 & 32 & 31 & Malam hari \\
\hline 6 & & 21.00 & 29 & 27 & 31 & 30 & Malam hari \\
\hline 7 & \multirow{10}{*}{ 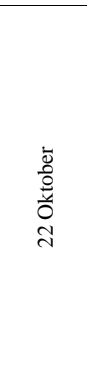 } & 09.00 & 36 & 32 & 30 & 32 & Cerah \\
\hline 8 & & 10.15 & 38 & 31 & 35 & 34 & $\begin{array}{c}\text { Tidak } \\
\text { terkena } \\
\text { sinar } \\
\text { matahari }\end{array}$ \\
\hline 9 & & 11.45 & 48 & 37 & 36 & 37 & Cerah \\
\hline 10 & & 12.10 & 52 & 42 & 35 & 42 & Cerah \\
\hline 11 & & 13.30 & 50 & 30 & 35 & 43 & Mendung \\
\hline 12 & & 14.45 & 44 & 31 & 36 & 38 & Cerah \\
\hline 13 & & 15.19 & 45 & 31 & 34 & 34 & Cerah \\
\hline 14 & & 16.00 & 42 & 31 & 35 & 36 & Berawan \\
\hline 15 & & 17.00 & 43 & 30 & 34 & 33 & Cerah \\
\hline 16 & & 20.00 & 30 & 28 & 31 & 31 & Malam hari \\
\hline 17 & \multirow{7}{*}{ 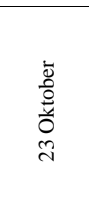 } & 09.00 & 34 & 30 & 34 & 34 & cerah \\
\hline 18 & & 10.45 & 39 & 31 & 33 & 35 & Cerah \\
\hline 19 & & 11.30 & 38 & 30 & 35 & 35 & Berawan \\
\hline 20 & & 12.00 & 38 & 31 & 32 & 33 & Mendung \\
\hline 21 & & 13.45 & 35 & 29 & 32 & 35 & Mendung \\
\hline 22 & & 14.30 & 33 & 29 & 33 & 38 & Mendung \\
\hline 23 & & 15.00 & 32 & 28 & 34 & 46 & Hujan \\
\hline \multicolumn{2}{|c|}{$\begin{array}{c}\text { Hasil } \\
\text { pengeringan }\end{array}$} & \multicolumn{4}{|c|}{ Berat awal : $9 \mathrm{Kg}$} & \multicolumn{2}{|c|}{$\begin{array}{c}\text { Berat akhir : 4,9 } \\
\text { Kg }\end{array}$} \\
\hline
\end{tabular}

Dari data diatas, didapatkan temperatur diluar ruangan bervariasi antara $27^{\circ} \mathrm{C}$ hingga $42^{\circ} \mathrm{C}$ dengan cuaca yang bervariasi pula dengan seringnya mendung mempengaruhi lamanya waktu pengeringan cenderung lebih lama sehingga dibutuhkan waktu sekitar 3 hari untuk proses pengeringan ikan kakap ukuran besar ini. Suhu rata-rata yang ada dalam ruang pengering ikan yaitu $37^{\circ} \mathrm{C}$. Perhitungan dengan berat awal ikan $9 \mathrm{Kg}$ dan berat akhir 4,9 $\mathrm{Kg}$ didapatkan kadar air sebagai berikut.

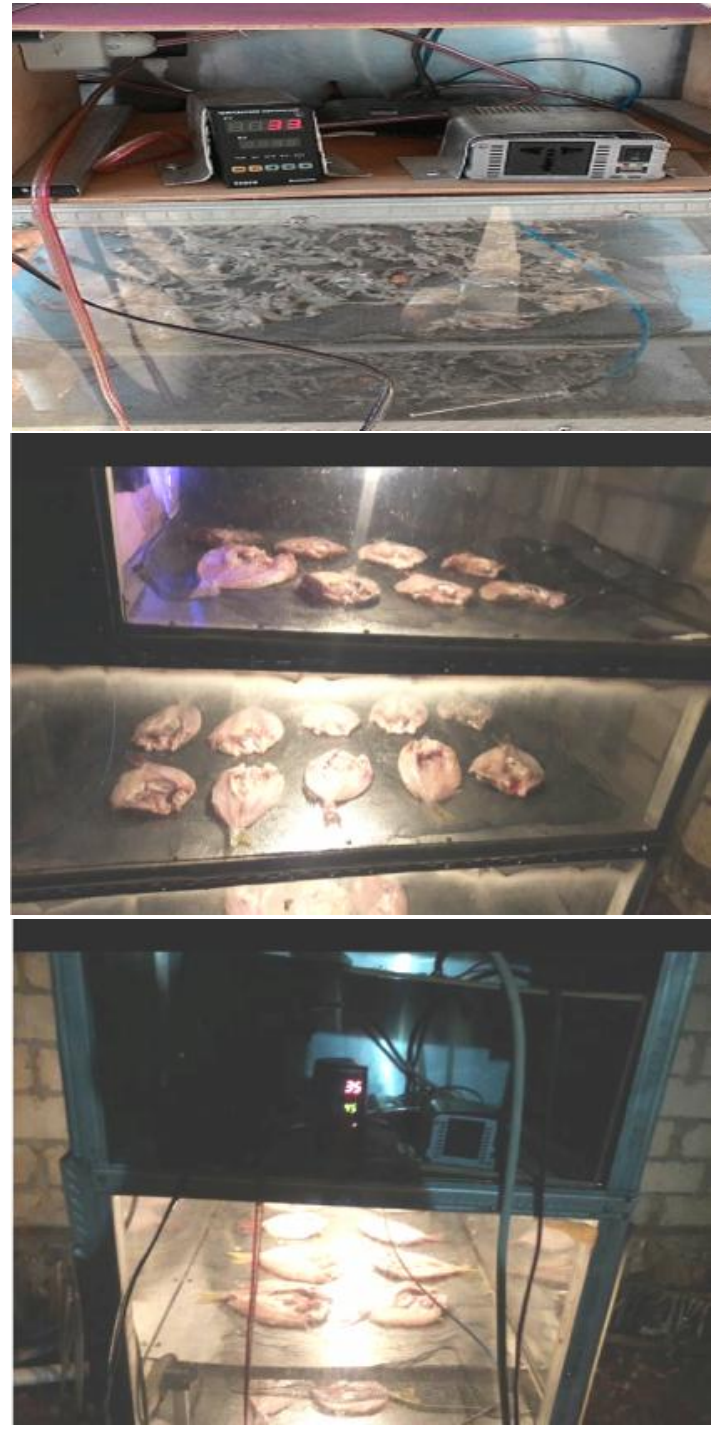

Gambar 8. Proses Pengeringan ikan dimalam hari

Dengan input referensi $45^{\circ} \mathrm{C}$, maka lampu menyala pada temperatur dibawah $45^{\circ} \mathrm{C}$, seperti terlihat pada gambar. temperatur dalam pengering ikan adalah $33^{\circ} \mathrm{C}$, sehingga lampu menyala. 


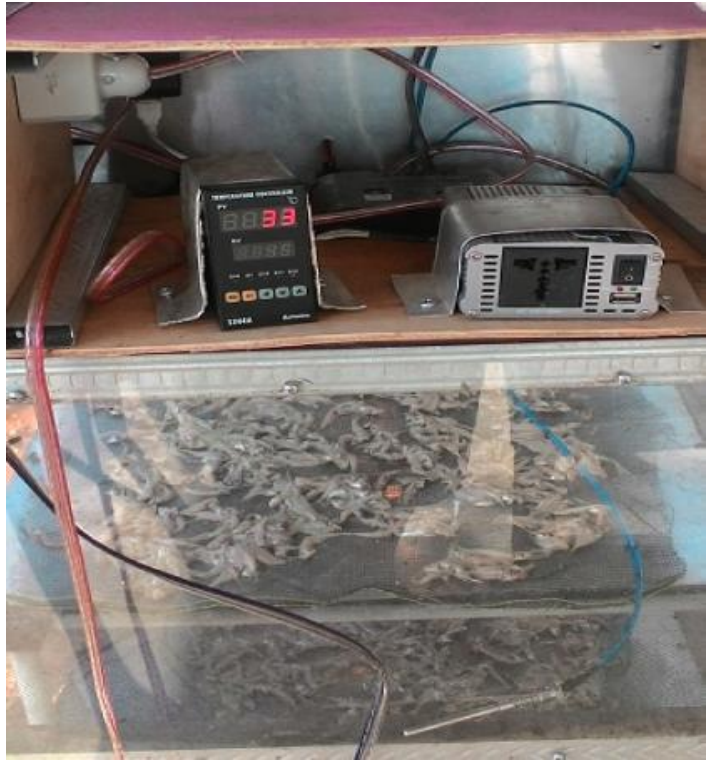

Pada siang hari temperatur dalam pengering ikan lebih besar dari $45^{\circ} \mathrm{C}$, pada gambar 14 . Temperatur mencapai $95^{\circ} \mathrm{C}$ maka lampu tidak menyala.

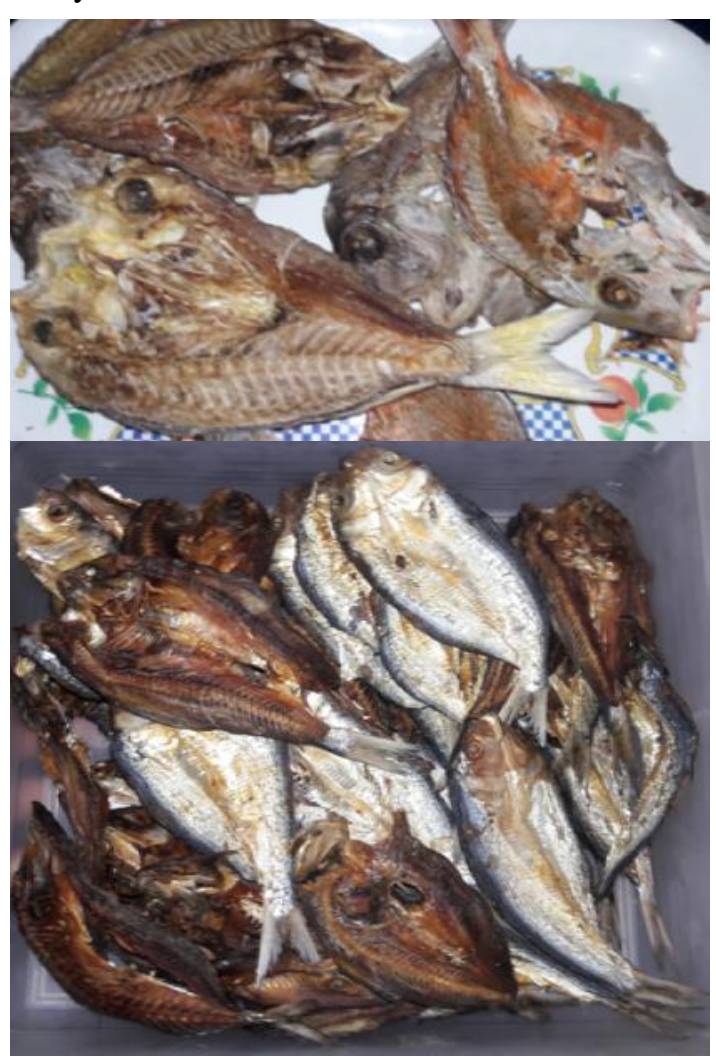

Gambar 9. Hasil Pengeringan ikan di malam hari

\section{KESIMPULAN}

\subsection{Kesimpulan}

Berdasarkan kegiatan yang sudah dilakukan dalam Tabel 1, maka kesimpulan sementara untuk penelitian dengan judul: Pemodelan alat pengering ikan ramah lingkungan dengan menggunakan integrasi panel surya dan sinar matahari langsung,

1.Pengontrolan suhu panas dalam ruangan pengering ikan menggunakan sensor temperature dan sensor kelembapan udara yang dijaga agar suhu berada dikisaran 37 sampai dengan $50^{\circ} \mathrm{C}$.

2.Sistem pembuangan kadar air hasil pengeringan dirancang saluran air dengan menggunakan bahan profil $U$ dari baja ringan yang ditempatkan dibawah kawat ram-ram tempat penempatan ikan.

3.Kipas angin dipasang pada masing-masing rak pengering dengan arah horizontal sehingga saat suhu ruangan naik, kontrol pengaturan akan menjalankan kipas angin.

4.Posisi pemasangan panel surya dapat ditempatkan langsung diatas rak pengering dengan jarak aman dimana kondensasi panas yang menyebar tidak boleh melebihi 50 derajat agar tidak mengganggu performance dari modul PV.

5.Untuk pengaturan suhu ruangan agar tidak lebih dari 50 derajat celcius maka system kontrol pengaturan suhu panas diatur agar mencapai 50 derajat kipas angin akan bekerja untuk menurunkan suhu, dan kerja sebaliknya akan diatur oleh sensor kelembaban.

6.Ikan kering berbagai jenis yang dihasilkan dalam kapasitas $10 \mathrm{~kg}$ pada alat pengering ikan tanpa lampu pijar 15 Watt dengan waktu pengeringan selama 3 hari, menggunakan lampu pijar 15 watt pada malam hari, waktu pengeringan ikan mencapai 2 hari dan menggunakan lampu pijar 15 watt ditambah kipas angin pada malam hari, waktu pengeringan ikan mencapai 2 hari.

7.Dengan menggunakan catu daya solar cell. Proses Pengaturan kontrol suhu dalam ruangan pengering ikan menggunakan 
Temperatur kontrol TNZ4H yang dihubungkan dengan sensor RTD dengan mengatur set Point $35-45^{\circ} \mathrm{C}$. Jika temperatur kurang dari $35^{\circ} \mathrm{C}$ maka sumber panas (Lampu) akan menyala apabila lebih dari $45^{\circ} \mathrm{C}$ maka lampu akan padam.

8. Hasil pengeringan ikan dengan ukuran sedang (ikan kombong) hanya membutuhkan waktu pengeringan sekitar 8 jam dengan rata-rata suhu dalam ruangan pengering $45{ }^{\circ} \mathrm{C}$. Sedangkan dengan ikan ukuran besar (Ikan kakap merah) membutuhkan waktu sekitar 3 hari karena dalam hal ini proses pengeringan masih membutuhkan matahari sebagai sumber panas dan sebagai sumber tenaga cadangan. Rata-rata suhu dalam rak saat proses pengeringan ikan besar adalah $37^{\circ} \mathrm{C}$.

9. Suhu maksimal dalam alat pengering ikan $55^{\circ} \mathrm{C}$ dengan suhu luar maksimal $42{ }^{\circ} \mathrm{C}$.

\subsection{Saran}

Dengan melihat hasil yang ada, teknologi pengering ikan ini perlu dikembangkan lagi.

1.Untuk mendapatkan waktu pengering ikan yang lebih singkat lagi dengan tingkat kekeringan ikan yang sempurna.

2. Alat pengering ikan menggunakan catu daya dari panel surya ini juga bisa diperbesar tergantung sesuai kebutuhan. Untuk produksi berkapasitas besar alat pengering dapat diperbesar atau ditambah jumlah rak pengeringnya.

3.Untuk mempercepat proses pengeringan dapat dilakukan dengan penambahan ukuran daya pada pemanas (Lampu pijar).

\section{DAFTAR PUSTAKA}

Bahari. 2010. Model Penyimpanan Energi Matahari Proses Pembuatan Garam Laut. Politeknik Negeri Kupang.

Cao, Fei, dan Liejin Guo. 2011. Simulasi of a sloped solar chimney power plant in Lanzhou. `ELVESIER.

Daryanto. 2007. Energi Masalah dan Pemanfaatannya Bagi Kehidupan Manusia. Yogyakarta: Pusaka Widyatama.

Energi Surya Biomassa untuk Pengering Ikan. Fakultas Teknik Universitas Syiah Kuala.

Daryanto. 2007. Energi Masalah dan Pemanfaatannya Bagi Kehidupan Manusia. Yogyakarta: Pusaka Widyatama.

Energi Surya Biomassa untuk Pengering Ikan. Fakultas Teknik Universitas Syiah Kuala.

Hasibuan Rosdaneli, 2005. Proses Pengeringan. Program Studi Teknik Kimia. Fakultas Teknik.

Handini. 2008. Performa Sel Surya. Fakultas Teknik Universitas Indonesia.

Regional Workshops on Drying Technology, Jakarta, 159-191. Sumatra Utara Zulfri, Syuhada, Hamdani. 2012. Kaji Eksperimental Sistem Pengering Hibrid.

Supranto,2015. Teknologi tenaga surya. Yogyakarta: Global pustaka Utama.

Yamato, ikwan .2013"mengenal aki" http:// yamatoikwan.blogspot.co.id/2013/03/ mengenal-accu-aki - akumulatorbaterai.html.

Zulfri, Syuhada, Hamdani. 2012. Kaji Eksperimental Sistem Pengering Hibrid Energi Surya Biomassa untuk Pengering Ikan. Fakultas Teknik Universitas Syiah Kuala. 